\title{
Periarticular calcific deposits mimicking acute arthritis
}

\author{
A. J. SWANNELL, F. A. UNDERWOOD, AND A. St J. DIXON \\ From the Royal National Hospital for Rheumatic Diseases, Bath, and the Department of Physics, Bath \\ University of Technology
}

Calcium salt deposition occurring outside joints must be distinguished from calcification due to pyrophosphate deposition within joint cartilage (chondrocalcinosis). Extra-articular deposits, localized to tendinous, capsular, and ligamentous tissue (Sandström, 1938), usually present as acute painful inflammation round the deposit, mimicking acute arthritis. Occasionally, they are discovered incidentally in a presymptomatic or mildly sypmtomatic phase.

\section{Material}

A series of 21 patients was studied, twelve at the Chelsea and Kensington Rheumatism Unit, St. Mary Abbots Hospital, Kensington, and nine at the Royal National Hospital for Rheumatic Diseases, Bath. Seventeen were seen in rheumatology out-patients departments and three were referred from the orthopaedic department. One patient was referred from the casualty department having been diagnosed as a case of acute gout. In the same time about 6,000 new patients were seen: therefore the condition is not very common.

The 21 patients (Table I) all presented with the sudden onset of acute pain and swelling in the area affected, with limitation of movement of the associated joint. All the cardinal signs of inflammation were present. In some, pain was severe enough to require morphia and aspiration of the deposit through a wide-bore needle. The tissue round the deposit was tender, sometimes exquisitely so. Deposits at the shoulder could sometimes be seen to move under the skin on rotation of the humerus; deposits

Table II Site of calcific deposits

\begin{tabular}{lll}
\hline Site & $\begin{array}{l}\text { No. of attacks } \\
\text { recorded at that } \\
\text { site }\end{array}$ & $\begin{array}{l}\text { Frequency of } \\
\text { patient } \\
\text { involvement }\end{array}$ \\
\cline { 2 - 3 } Finger & 4 & 2 \\
Wrist & 2 & 2 \\
Shoulder & 26 & 17 \\
Hip & 3 & 3 \\
Knee & 1 & 1 \\
Great toe & 6 & 6 \\
\hline
\end{tabular}

elsewhere could not be detected clinically. The acute stage lasted for from 2 days to 4 weeks, the average being 6 days; this was much the same whatever the site of the deposit. The signs of inflammation then gradually subsided and movement of the joint returned. There were two exceptions to this, and one patient, whose symptoms persisted for 6 months, required surgery.

\section{Observations}

Radiographs of the area, taken with careful soft tissue exposure and positioning of the site of the deposit, provided confirmation in all except four attacks (Fig. 1). In these four, diagnosis was made on the clinical history and the occurrence of other radiologically confirmed deposits in the same patient.

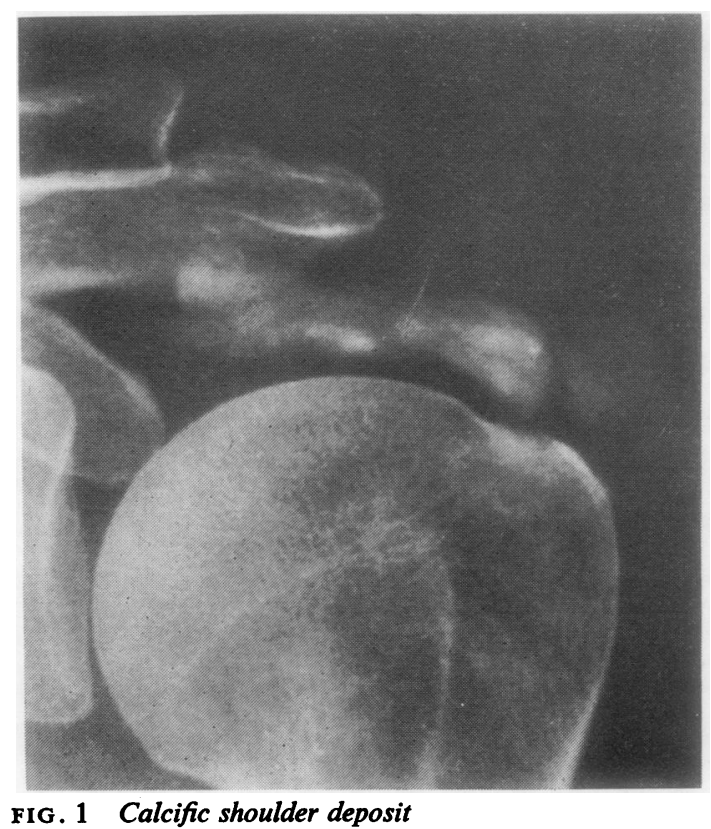

After the acute stage, the deposit decreased in size, often rapidly. Deposits were observed to disappear in as little as 2 weeks at one extreme and to persist 
Table I Clinical particulars of 21 patients

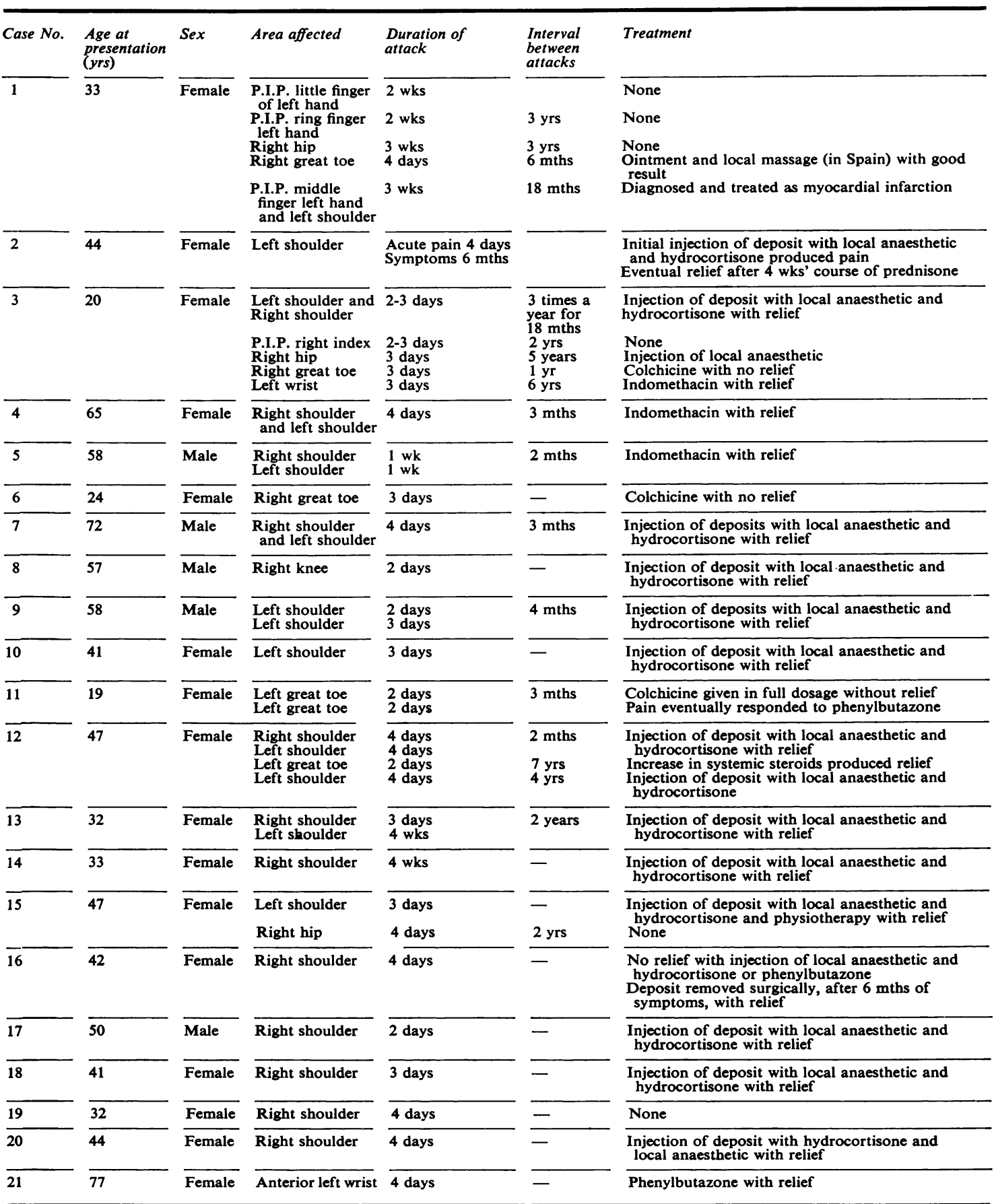


for 7 months at the other. In two patients the deposit ruptured into the subacromial bursa, producing an acute bursitis with a milky radio-opaque aspirate. This led to secondary inhibition of muscle tone and temporary subluxation at the shoulder (Fig. 2).

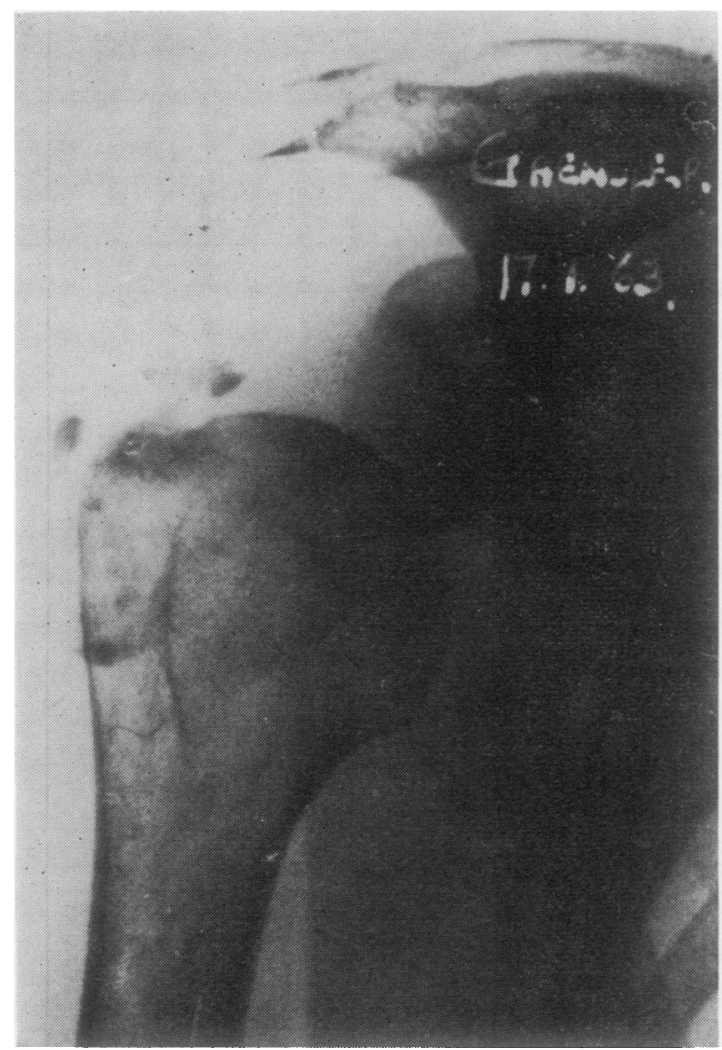

FIG. 2 Rupture of a calcific deposit into subacromial bursa, producing subluxation at the shoulder

As in previous series, Sandström (1938) and Gondos (1957), the shoulder was the commonest area affected but no area was immune (Table II). Those who presented with acute attacks in the shoulder also gave a previous history of occasional episodes of pain and stiffness from 3 months to 3 years before the onset of the acute attack.

Five patients presented with acute podagra indistinguishable from that of acute gout and three patients were treated as cases of gout before the calcific deposit was recognized (Figs 3 and 4). All five were young premenopausal women with no family history of gout and normal blood concentrations of urate. In only one woman with calcific podagra was the blood urate raised. Numerous other biochemical investigations performed were all normal. The erythrocyte sedimentation rate was often raised in the acute phase (Table III, opposite).

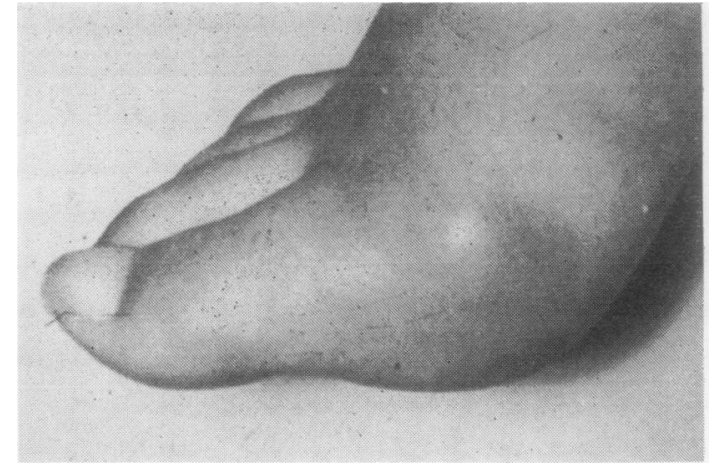

FIG. 3 Photograph of foot of Case 6, presenting as acute podagra

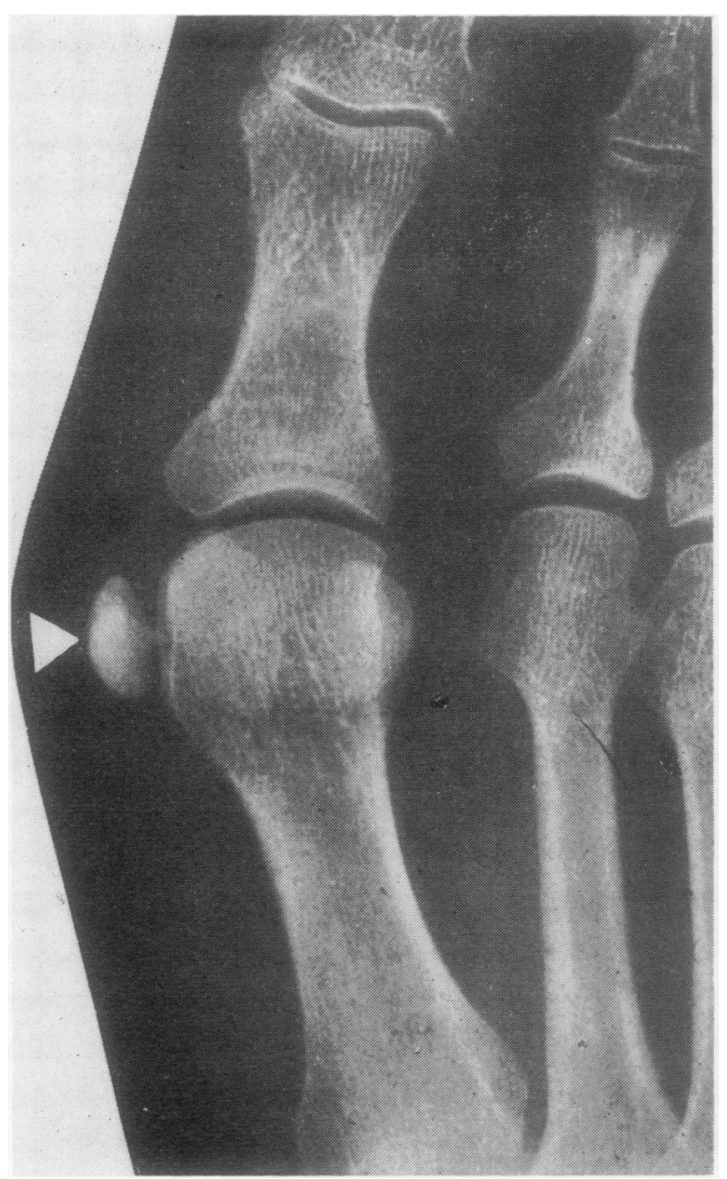

FIG. 4 Radiograph of right foot of Case 6, showing calcific deposit on medial aspect of first MTP joint

\section{IDENTIFICATION OF DEPOSIT}

Patient 16 had pain in the shoulder which persisted for 6 months in spite of local treatment. A small deposit, removed from the supraspinatus tendon 
Table III Results of laboratory investigations in 19 patients

\begin{tabular}{|c|c|c|c|c|c|c|c|c|c|c|c|c|c|c|c|c|c|c|c|}
\hline Investigations & 1 & 2 & 3 & 4 & 5 & 6 & 7 & 8 & 9 & 10 & 11 & 12 & 13 & 14 & 15 & 16 & 17 & 18 & 19 \\
\hline $\begin{array}{l}\mathrm{Hb}(\mathrm{g} . / \\
100 \mathrm{ml} .)\end{array}$ & $13 \cdot 8$ & $13 \cdot 2$ & $14 \cdot 2$ & - & $15 \cdot 8$ & $12 \cdot 4$ & $14 \cdot 1$ & - & - & - & $12 \cdot 0$ & $12 \cdot 5$ & $11 \cdot 8$ & $11 \cdot 8$ & $14 \cdot 8$ & - & - & $12 \cdot 8$ & $13 \cdot 4$ \\
\hline $\begin{array}{l}\text { ESR } \\
(\mathrm{mm} . / \mathrm{hr})\end{array}$ & - & 45 & 15 & - & - & - & 10 & - & - & - & 40 & 8 & 47 & 8 & 6 & - & - & 22 & 11 \\
\hline $\begin{array}{l}\text { WBC (cells/ } \\
\text { hp field) }\end{array}$ & 8,600 & 10,700 & 16,600 & - & 11.900 & 11,900 & 11,500 & - & - & - & 6,000 & 7,500 & - & 5,000 & 6,000 & - & - & 6,800 & 8,000 \\
\hline $\begin{array}{r}\text { Urea (mg/ } \\
100 \mathrm{ml} .)\end{array}$ & 37 & - & - & - & - & - & - & - & 40 & - & 20 & - & - & - & 37 & 44 & 32 & 28 & 45 \\
\hline $\begin{array}{l}\text { Uric acid } \\
\text { (mg./100 } \\
\text { ml.) }\end{array}$ & 6 & - & $5 \cdot 2$ & - & $5 \cdot 4$ & $5 \cdot 4$ & - & $5 \cdot 4$ & - & - & $4 \cdot 6$ & $4 \cdot 0$ & - & $3 \cdot 9$ & $4 \cdot 4$ & $3 \cdot 4$ & $5 \cdot 0$ & $6 \cdot 1$ & $3 \cdot 6$ \\
\hline $\begin{array}{l}\text { Calcium (mg } \\
\text { per cent.) }\end{array}$ & $9 \cdot 7$ & - & $9 \cdot 8$ & - & - & - & $9 \cdot 0$ & $9 \cdot 0$ & - & - & $9 \cdot 0$ & $9 \cdot 5$ & - & $9 \cdot 8$ & $11 \cdot 0$ & $\overline{10 \cdot 1}$ & $10 \cdot 1$ & - & $10 \cdot 6$ \\
\hline $\begin{array}{l}\text { Phosphate } \\
\text { (mg. per } \\
\text { cent.) }\end{array}$ & $3 \cdot 5$ & - & $3 \cdot 0$ & - & - & - & $2 \cdot 7$ & $2 \cdot 4$ & - & - & $3 \cdot 3$ & $2 \cdot 3$ & - & $3 \cdot 0$ & $3 \cdot 6$ & $3 \cdot 5$ & $3 \cdot 1$ & - & $3 \cdot 7$ \\
\hline $\begin{array}{l}\text { Alkaline } \\
\text { phosphatase } \\
\text { (K.A. units) } \\
100 \text { ml.) }\end{array}$ & 15 & - & $4 \cdot 7$ & - & - & - & 10 & $5 \cdot 5$ & $8 \cdot 7$ & - & - & - & - & 6 & 11 & 7 & $\overline{8}$ & - & 10 \\
\hline
\end{tabular}

(Heggö, 1964; Duncan, 1968), was a gritty white mass, radio-opaque and microscopically amorphous. No crystals were seen under polarized light microscopy, and chemical analysis showed the deposit to consist of calcium carbonate and phosphate. $X$-ray diffraction studies were performed on the powder and the pattern was found to be that of hydroxyapatite (Fig. 5).

\section{Discussion}

James Lindsay (1913), writing on gout from this Hospital, quotes Wildbolz (1902), who described the case of a woman aged 57, who exhibited all the symptoms of acute gout affecting the hands. The deposits on the palmar surfaces ultimately ulcerated, exuding a granular pultaceous chalky material, which was found to consist of phosphates and carbonates. The great toe joints had at an earlier period been similarly affected. It was conjectured that in this case the urates which had been originally present had been absorbed so completely that no trace remained.

Painter (1907) was the first to show that the deposits were radio-opaque in the subacromial bursa. Sandström (1938) and Gondos (1957) observed them in tendons near other joints and Sandström (1938) also noted disappearance of the deposit after the acute phase had resolved.

Sandström (1938), Pinals and Short (1966), and Thompson, Ming Ting, Riggs, Fenn, and Reynolds (1968) commented on the clinicial similarity of periarticular calcification to acute gout. The male : female ratio varies in different series: Sandström $169: 160$; Pinals and Short $1: 3$; Thompson and others $3: 5$. In our series females were affected more often than males ( 5 males : 16 females) in contrast

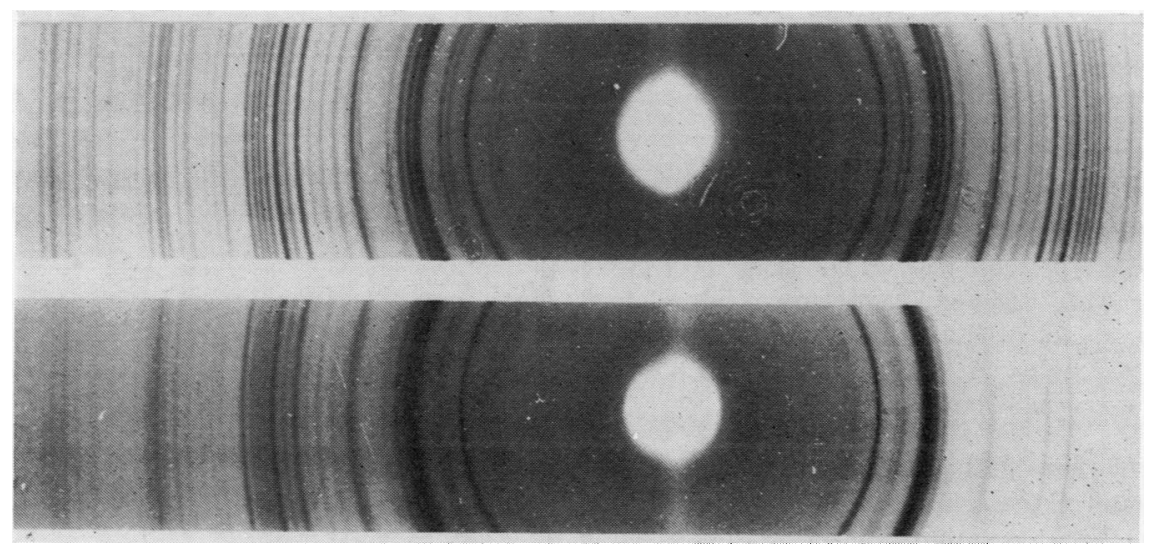

FIG. $5 X$-ray diffraction pattern

Diffraction pattern of known hydroxyapatite crystal (upper)

Diffraction pattern of sample from Case 16 (lower) 
to the male preponderance in gout. The average age at presentation in our series was 44 years and three patients were in their early twenties. Three patients had a family history of 'gout' but no evidence of gout themselves and three had a family history of arthritis but no evidence of specific arthritis.

There has been no controlled trial of treatment, other than irradiation (Plenk, 1952) which was ineffective; this is reflected in the variety of treatments suggested by others: hot and cold compresses; shortwave diathermy (Key, 1949); ultra-violet blood irradiation (Neff and Anderson 1951); immobilization in plaster (Key, 1949; Seidenstein, 1950); penicillin (Krook, 1954); surgery (Heggö, 1964).

In our series pain was sufficient in two patients to require morphia and aspiration through a widebore needle. Less severe pain responded to phenylbutazone or indomethacin in the dosage used for acute gout. Colchicine failed to relieve pain in three of the patients with acute podagra as opposed to the dramatic response claimed by Thompson and others (1968). Injection of the deposit with hydrocortisone and local anaesthetic was used with apparent success in patients with persistent deposits, especially at the shoulder. One patient whose symptoms persisted for 6 months had the deposit successfully removed at operation from the supraspinatus tendon.

Patients are liable to further attacks near the same or other joints and should be warned about this. Recurrence at the same joint was noted in six of the twenty patients; in fifteen patients more than one periarticular area was subsequently involved. One of our patients (Case 3), who had had 20 years' experience of painful deposits in many areas, can now sense when she is about to have an attack and takes prophylactic indomethacin with relief.

The aetiology of this disease remains unknown. Trauma has been implicated (Bosworth, 1941; Cooper, 1942; Gondos, 1957). Codman (1934) suggested that certain occupations were more liable, but there was no evidence to support this in our patients. Local infection has been suggested, but cultures from the calcified areas (Elmslie, 1932; Key, 1949) were sterile. Disturbance of calcium metabolism is an obvious possibility, but so far (Cooper, 1942; Key, 1949; McCarty and Gatter, 1966) none has been detected.

The calcific deposits have recently been examined again in detail (Pinals and Short, 1966; McCarty and Gatter, 1966). Codman (1934) found a white amorphous mass composed of many small round or ovoid bodies. $X$-ray diffraction studies (Pinals and Short, 1966; McCarty and Gatter, 1966) of the main mass of the deposit material have shown this to consist of hydroxyapatite. Chemically hydroxyapatite is $3 \mathrm{Ca}_{3}\left(\mathrm{PO}_{4}\right)_{2} \mathrm{Ca}(\mathrm{OH})_{2}$, and its composition is modified by the ions substituted at the surface of the crystal; carbonate may substitute for phosphate. Crystals of hydroxyapatite can be seen with the electron microscope $(0 \cdot 15 \mu)$ in denatured bone (Robinson and Watson, 1952), but are too small to be seen with the optical microscope.

McCarty and Gatter (1966) have also identified small, irregular, weakly birefringent particles, but these have not been chemically identified. Inflammation in periarticular calcific deposits bears a striking resemblance to acute urate gout, i.e. a crystal-induced inflammation. The trigger could be the unidentified crystals rather than the amorphouslooking hydroxyapatite. The phlogistic power of hydroxyapatite itself has not been investigated, but in other biochemical situations, e.g. the walls of calcified arteries in diabetics, it appears inert.

Histologically, Sandström (1938) found necrosis and necrobiotic changes in the tendons, ligaments, and joint capsule. In ten patients there was hypertrophy of the media and occlusion of several small arteries. He suggested that the vascular changes might be primary and that the calcific deposits were secondary to 'local tissue anaemia with impaired vitality'. Sandström did not give the age of the deposits and tissue examined, and more recently (Moseley, 1963) found that the tendon was well vascularized around the area of the deposit'. Moseley suggested that necrosis of tendon resulted from increasing deposition with death of the tendon fibres probably due to pressure and tension.

\section{Summary}

Nineteen patients with periarticular calcific deposits presenting as acute arthritis are described. Their subsequent history and investigations are tabulated and the similarity of the clinical presentation to acute gout is stressed.

The nature of one deposit was identified by chemical, microscopical, and $x$-ray diffraction analysis as hydroxyapatite.

We should like to thank Dr. J. A. Cosh, Dr. M. I. V. Jayson, and Mr. P. Yeoman who kindly referred patients.

Mr. F. A. Underwood of the School of Physics, Bath University of Technology, performed the $x$-ray diffraction study on the deposit removed from Case 16. 


\section{References}

Bosworth, B. M. (1941) J. Amer. med. Ass., 116, 2477 (Calcium deposits in the shoulder and subacromial bursitis. A survey of 12,122 shoulders).

Codman, E. A. (1934) 'The Shoulder' pp. 186-187; 81-82. Boston, Mass.

COOPER, W. (1942) J. Bone Jt Surg., 24, 114 (Calcareous tendinitis in the metacarpophalangeal region).

DuncaN, G. A. (1968) V. med. Mth., 95, 11 (Surgical treatment of calcific sub-acromial tendinitis).

ElmsLIE, R. C. (1932) Brit. J. Surg., 20, 190 (Calcareous deposits in the supraspinatus tendon).

Gondos, B. (1957) Amer. J. Roentgenol., 77, 93 (Observations on periarthritis calcarea).

HeGGö, O. (1964) Acta orthop. scand., 35, 126 (Tendinitis calcarea supraspinati).

KEY, J. A. (1949) Ann. Surg., 129, 737 (Calcium deposits in the vicinity of the shoulder and of other joints).

Krook, S. S. (1954) Nord. Med., 51, 136 (Peritendinitis calcarea).

MCCARTY, D. J., AND GATTER, R. A. (1966) Arthr. and Rheum., 9, 804 (Recurrent acute inflammation associated with focal apatite crystal deposition).

Moseley, H. F. (1963) Surg. Clin. N. Amer., 43, 1489 (The natural history and clinical syndromes produced by calcified deposits in the rotator cuff).

NefF, F. E. AND ANDERSON, C. M. (1951) Amer. J. Surg., 81, 622 (Use of ultraviolet blood irradiation in the treatment of bursitis and tendinitis calcarea).

PaINTER, C. F. (1970) Boston med. surg., J. 156, 345 (Subdeltoid bursitis).

PINALS, R. S., AND SHORT, C. L. (1966) Arthr. and Rheum., 9, 566 (Calcific periarthritis involving multiple sites).

Plenk, H. P. (1952) Radiology, 59, 384 (Calcifying tendinitis of the shoulder-A critical study of the value of $x$-ray therapy).

Robinson, R. A., AND WATSOn, M. L. (1952) Anat. Rec., 114, 383 (Collagen-crystal relationships in bone as seen in the electron microscope).

SandStröm, C. (1938) Amer. J. Roentgenol, 40, 1 (Peritendinitis calcarea. A common disease of middle life: its diagnosis, pathology and treatment).

Seidenstein, H. (1950) J. Bone Jt Surg., 32A, 413 (Acute pain in the wrist and hand associated with calcific deposits-Report of fifteen cases).

Thompson, G. R., Ming Ting, Y., Riggs, G. A., Fenn, M. E., and Denning, R. M. (1968) J. Amer. med. Ass., 203, 464 (Calcific tendinitis and soft-tissue calcification resembling gout).

Wildbolz, H. (1902) Corr. Bl. schweiz. Aerzte, 32, 232. Quoted by LiNDSAY, J. (1913) in 'Gout. Its Aetiology, Pathology and Treatment', p. 115. Frowde and Hodder and Stoughton, London. 